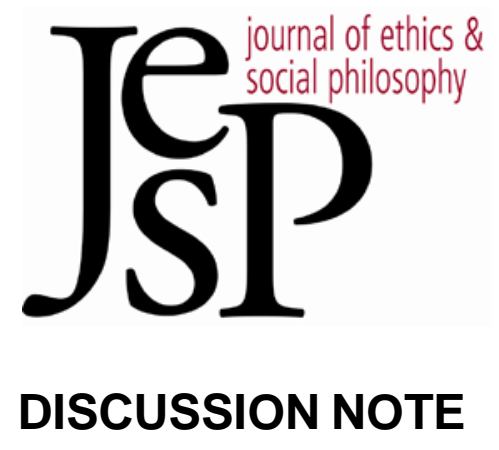

\title{
Relational Expressivism and Moore's Paradox
}

By TEEMu Toppinen

JOURNAL OF ETHICS \&SOCIAL PHILOSOPHY

DiscussiOn NOTE | JULY 2015

URL: WWW.JESP.ORG

COPYRIGHT (C) TEEMU TOPPINEN 2015 


\title{
Relational Expressivism and Moore's Paradox
}

\author{
Teemu Toppinen
}

\section{T XPRESSIVISTS OFTEN APPEAL TO THE FOLLOWING THESIS:}

(PARITY) Moral sentences express desire-like states (e.g., being in favor of or against something) in exactly the same way as a nonmoral sentence " $p$ " expresses a belief that $p$.

Jack Woods $(2014,2015)$ has recently argued that this thesis is false. If Woods is correct, this constitutes an important challenge for expressivism. It is not clear, after all, that an expressivist-friendly account of the expression relation can be combined with rejecting PARITY (see Schroeder 2008). Woods's (2014) argument goes as follows:

(i) The way in which nonmoral sentences express beliefs explains why sentences of the form " $p$, but I do not believe that $p$," where " $p$ " is a nonmoral sentence, are Moore-paradoxical.

(ii) If PARITY is true, then the way in which moral sentences express desirelike states should explain why sentences such as "Murder is wrong, but I am in no way against it" are Moore-paradoxical.

(iii) These latter kinds of sentences are not Moore-paradoxical. So:

(iv) PARITY is not true.

In an earlier paper, I suggested that this argument can be resisted (Toppinen 2014). It is a familiar thought that a sentence such as "Murder is wrong" may, depending on the context of utterance, express, for example, a genuine moral judgment condemning murder, or a merely descriptive judgment to the effect that murder fails to meet some salient, descriptively specifiable standards (e.g., the standards that have currency in the speaker's society). So, my suggestion was that sentences such as "Murder is wrong, but I am in no way against it" remain Mooreparadoxical if understood as making genuine moral claims, but are not Moore-paradoxical on nonmoral readings. This explains the impression shared by many, but not by everyone - that this sentence is not Mooreparadoxical in the same way as, say, the sentence "It is raining, but I do not believe that it is raining."

My proposal is challenged in a recent response by Woods (2015). I argue that, although Woods is right that my answer to his argument should not be developed in the contextualist or "ecumenical" ways that he considers, PARITY remains defensible on "relational" expressivist views.

Woods (2015) takes my suggestion to be that we modify PARITY as follows:

(WEAK PARITY) When moral sentences express desire-like states (e.g., being in favor of or against something), they do so in exactly the same way as a nonmoral sentence " $p$ " expresses a belief that $p$. 
I suppose we could put it this way. Alternatively, we may understand moral sentences to be sentences such as "Murder is wrong" when these sentences are used in certain ways (and, according to the expressivist, express desire-like states rather than some nonmoral beliefs). We may then stick with PARITY, which is what I will do in what follows. I take it that this is a merely terminological issue.

The challenge, now, is to explain how the moral and nonmoral uses of sentences such as "Murder is wrong" are systematically related. Without this kind of story, my proposal on behalf of the expressivists is bound to seem incredibly ad hoc. In my earlier response to Woods, I suggested that "when we use the sentence "Murder is wrong," for example, we always, very roughly, characterize murder in relation to standards or norms of a certain kind" (Toppinen 2014: 2). In some contexts, "Murder is wrong" could be used to state that murder is not allowed by the standards of one's society. In others, I suggested, this sentence would relate "murder to standards that the speaker herself endorses - where endorsement is understood in terms of some suitable desire-like states."

Woods (2015: 2-3) offers two ways of understanding this proposal. According to the contextualist view, "Murder is wrong" always expresses a belief with a nonmoral content, ascribing to murder some nonnormative property as determined by the context. On one simple way of understanding this view, the content of a belief expressed by "Murder is wrong" is, in moral contexts, determined by the standards endorsed by the speaker. Let us suppose that I am a hedonistic utilitarian. On this view, when I make a moral judgment using the sentence "Murder is wrong," the content of my judgment is that murder fails to maximize happiness. According to the ecumenical view, when I make a moral judgment using the sentence "Murder is wrong," I express my endorsement of certain standards as well as a belief that those standards rule out murder (cf. Ridge 2006).

Woods (2015: 2-3) argues that these proposals fail to capture PARITY. When I assert that it is raining, this directly commits me to believing that it is raining. However, according to the contextualist view and the ecumenical view, my assertion of "Murder is wrong" only directly commits me to a certain belief, or to a certain belief and a certain desire-like attitude, which then derivatively commit me to being against murder. On the contextualist view, my assertion expresses my belief that murder fails to maximize happiness. Given that the content of this belief is determined by my standards - by my being against certain kinds of things - I am then derivatively committed to being against murder. On the ecumenical view, my assertion expresses both my being against certain sorts of actions and my belief that murder is of that sort. Being in these states then commits me to being against murder.

Woods is correct that these ways of sharpening my proposal fail to give the result that "Murder is wrong" expresses a state of being against murder in just the same sense that "Snow is white" expresses a belief that snow is white. However, this is actually completely irrelevant to the plausibility of PARITY. Woods (2014) originally operates with the idea that, on an expressivist view, "Murder is wrong" would express something like 
being against murder - a state that has the action-type of murdering as its object. I do the same in my earlier response to Woods (Toppinen 2014). However, the contextualist view and the ecumenical view do not say that "Murder is wrong" expresses a state of being against murder. And so it cannot be a problem for the combination of either of these views plus PARITY that they predict disparity between the sense in which "Snow is white" expresses a belief that snow is white and the sense in which "Murder is wrong" expresses being against murder.

My aim is not to defend either the contextualist view or the ecumenical view, though. On the contextualist view, moral sentences do not directly express desire-like states at all. This view fails to capture PARITY and is not even supposed to do so. It is indeed not worth the name "expressivism." One might be tempted to try to combine the ecumenical view with PARITY, and suggest that "Murder is wrong" expresses, when uttered by a hedonistic utilitarian, a desire-like state toward actions insofar as they promote happiness - and does so in exactly the same sense as the sentence "Snow is white" expresses a belief that snow is white. But this would generate bad results. This view would predict that the following sentence would be incoherent, when uttered by a hedonistic utilitarian:

(E) Murder is wrong, but I am not against failing to maximize happiness.

But clearly (E) is not incoherent. And so, even when we test Mooreparadoxicality with the right desire-like states, the ecumenical view fails to capture PARITY.

However, my suggestion that in the moral contexts the sentence "Murder is wrong" relates murder to the standards that the speaker endorses can be developed in a way that is different from both the contextualist and the ecumenical views. According to the contextualist and ecumenical views, whenever I assert "Murder is wrong," I express a descriptive belief $-\mathrm{a}$ belief that (roughly) murder is ruled out by certain descriptively specifiable standards. We may reject this idea and yet accept that all assertions of the sentence "Murder is wrong" relate murder to standards that rule it out. We can say this: Sometimes, when I assert "Murder is wrong," I am asserting that murder is ruled out by certain descriptively specifiable standards, as determined by the context (e.g., the standards with currency in the speaker's society); at other times, when I assert "Murder is wrong," I am asserting that murder is ruled out by the right or the correct or the acceptable standards. Some uses of "Murder is wrong" express descriptive beliefs; some express normative (e.g., moral) beliefs. Or we might even put it this way: Some uses of "Murder is wrong" describe murder as bearing a relation to certain descriptively specifiable standards; some other uses describe murder as bearing a relation to the correct standards. The contemporary expressivist, who is very likely to be a quasi-realist, will probably be perfectly happy to accept these claims. She or he will just wish to explain the nature of moral beliefs as fundamentally 
desire-like, moral assertions and moral descriptions as expressions of these desire-like beliefs, and so on. ${ }^{1}$

If a story along these lines can be made to work, the expressivist is in a position to capture the systematic relation between the moral and nonmoral uses of sentences such as "Murder is wrong." The crucial questions now are: What is it, according to the expressivist, to use the sentence "Murder is wrong" in its moral sense? That is, what is it to assert that murder is ruled out by the correct moral standards? What kind of state is being expressed? And do we get the right predictions with regard to Moore-paradoxicality? I next outline two expressivist views that give us nice results. Here are the views:

(RELATIONAL EXPRESSIVISM 1 ) "Murder is wrong" expresses, in moral contexts, the (massively multiply realizable) relational state of having (a) a state of being against things with certain properties, $K_{1}, \ldots, K_{n}$, and (b) a suitably related belief (e.g., a belief that murder has one of the properties $K_{1}, \ldots, K_{n}$ ). ${ }^{2}$

(RELATIONAL EXPRESSIVISM 2 ) "Murder is wrong" expresses, in moral contexts, (1) the (massively multiply realizable) relational state of having (a) a state of being against things with certain properties, $K_{1}, \ldots, K_{n}$, and (b) a suitably related belief (e.g., a belief that murder has one of the properties $K_{1}, \ldots, K_{n}$ ), as well as (2) a state of being against murder, which is based on some realizers for the relational state, $(1) .^{3}$

The idea is this. Let us consider our hedonistic utilitarian who is against failing to maximize happiness and believes that murder fails to maximize happiness. Let us also consider a Kantian who is against failing to act in accordance with the Categorical Imperative and believes that murder fails to be in accordance with the Categorical Imperative. The utilitarian's and the Kantian's states of being against and believing are, respectively, similarly related. The utilitarian and the Kantian both are against some sorts of things, and believe that murder is of the relevant sort. They are, then, both in the kind of relational state that, according to relational expressivism $_{1}$, is expressed by "Murder is wrong." Now, suppose that the utilitarian and the Kantian are both also against murder. The utilitarian is against

\footnotetext{
1 There are at least two ways one could further develop this line of thought. One could say that there is a unified core meaning for the sentence "Murder is wrong," in that this sentence is always suited for stating, roughly, that murder is ruled out by standards of some relevant sort (see Ridge 2014, ch. 1). In some contexts, a use of this sentence would then advert (say) to the standards with currency in the speaker's society; in others it would advert to the correct or the acceptable standards. Alternatively, one could suggest that there is, strictly speaking, no shared core meaning for the nonnormative and normative uses of this sentence, but, given that both uses involve the idea that murder is ruled out by standards of some kind, there is sufficient similarity between the different meanings that it makes sense that the same word, "wrong," is used in both cases.

${ }^{2}$ The value of $K_{1}, \ldots, K_{n}$ may vary from one person to another. For relational expressivism, see Schroeder (2013), Toppinen (2013) and Ridge (2014).

3 The value of $K_{1}, \ldots, K_{n}$ may again vary from one person to another. On this view, "Murder is wrong," as used by me in circumstances $C$, expresses my being against murder, where this state must be based on some suitably related states of being against and believing, but these particular states of being against and believing are not themselves expressed in any relevant sense by this sentence.
} 
murder because she is against failing to maximize happiness and believes that murder constitutes a failure in this respect; the Kantian is against murder because she is against failing to act in accordance with the Categorical Imperative and believes that murder constitutes a failure in this respect. They are, then, both in a state of being against murder such that is, according to relational expressivism ${ }_{2}$, expressed by "Murder is wrong."

Relational views have perhaps only recently been articulated as clearly distinctive alternatives for an expressivist. But the basic idea here is not at all new. Simon Blackburn, for instance, is often taken to advocate a "pure" expressivist view, on which "Murder is wrong" would only express desire-like states (perhaps disapproval of murder, as well as some higher-order attitudes, including attitudes toward others' attitudes toward murder). But the descriptive beliefs clearly play a role in his account, as evidenced by his writing, for instance, that when "someone reports that Johnny did something good, there is some property of deeds that [she] admires, and she believes Johnny did a deed with that property" (Blackburn 1998: 76). There may be many reasons, for someone inclined toward pure expressivism, to go relational and give descriptive beliefs a role in the explanation of the meaning of moral sentences. One such reason important in the present context - is that this allows the expressivist to capture, with some plausibility, the thought that the meaning of "Murder is wrong" always has to do with the relation of murder to some suitable standards. This helps in accounting for there being a systematic relation between the moral and nonmoral uses of this sentence.

Still, according to the relational expressivist views outlined above, "Murder is wrong" never expresses, in its moral use, anything like a belief that (for example) murder fails to meet the utilitarian standard. The sentence does not express this belief even in a utilitarian's mouth. It expresses the same state in everyone's mouth. Everyone's assertion of "Murder is wrong" says - in moral contexts - that murder is ruled out by the correct moral standards. These assertions always express a certain kind of relational state (if relational expressivism $\mathrm{m}_{1}$ is true), or a state of being against murder, which is based on some states that realize that kind of relational state (if relational expressivism $\mathrm{i}_{2}$ is true).

What kinds of predictions do these views generate vis-à-vis Mooreparadoxicality? If relational expressivism ${ }_{2}$ is true, then "Murder is wrong, but I am in no way against murder" should clearly come out as incoherent, given a moral reading. This seems right. We are, in the present context, taking for granted that one could pursue the strategy of distinguishing between the moral and the nonmoral uses of sentences such as "Murder is wrong," and suggest that, to the extent that the sentence "Murder is wrong, but I am in no way against murder" seems coherent, we are taking it in a nonmoral way. So, on this view, PARITY is vindicated. ${ }^{4}$

4 As is pointed out by Woods (2015: 2, n. 2), in response to an anonymous reviewer, a full development of this kind of defense strategy on behalf of the expressivist should give us an account of the mechanisms through which the context determines whether a moral or a nonmoral judgment is being expressed by a sentence. Like Woods, I will set 
How about relational expressivism, ${ }_{1}$ ? On this view, "Murder is wrong" does not directly commit one to being against murder. And so, on this view, "Murder is wrong, but I am in no way against murder" does not come out as incoherent in the same way as "Snow is white, but I do not believe that snow is white" does. That is fine, though; the relevant test cases for relational expressivism ${ }_{1}$ are different. They are something like the following:

(RE) Murder is wrong, it really is, but I am in no way against the kinds of actions that murders are.

(RE*) Murder is wrong, it really is, but what I am against does not include actions of that type. ${ }^{5}$

But these, too, seem clearly incoherent, when given a moral reading. PARITY is, again, vindicated.

Although I have argued that Woods' reasons for thinking that the contextualist view and the ecumenical view fail to capture PARITY are in part mistaken (it is quite all right that they do not secure the Mooreparadoxicality of "Murder is wrong, but I am in no way against it"), he is right that these views do fail to make sense of PARITY. Gladly, expressivists have other options. At least certain forms of relational expressivism allow us to capture PARITY, and so survive Woods' challenge. ${ }^{6}$

Teemu Toppinen

University of Helsinki

Department of Political and Economic Studies

teemu.toppinen@helsinki.fi

this issue to one side here. However, it is worth emphasizing that the success of my defense of expressivism is conditional on some suitable account being available.

5 This test sentence was suggested to me by Jack Woods.

${ }^{6}$ I thank the two anonymous reviewers and Jack Woods for the helpful comments and the Kone Foundation for the useful money (as well as for general awesomeness). 


\section{References}

Blackburn, S. (1998) Ruling Passions, Oxford: Oxford University Press.

Ridge, M. (2014) Impassioned Belief, Oxford: Oxford University Press.

(2006) “Ecumenical Expressivism: Finessing Frege," Ethics 116: 302-36.

Schroeder, M. (2013) “Tempered Expressivism," in R. Shafer-Landau, ed., Oxford Studies in Metaethics, Vol. 8, Oxford: Oxford University Press. (2008) "Expression for Expressivists," Philosophy and Phenomenological Research 76: 86-116.

Toppinen, T. (2014) "Expressivism and Moore's Paradox: A Reply to Woods," Journal of Ethics and Social Philosophy.

(2013) "Believing in Expressivism," in R. Shafer-Landau, ed., Oxford Studies in Metaethics, Vol. 8, Oxford: Oxford University Press.

Woods, J. (2015) “Expressivism Worth the Name: A Reply to Teemu Toppinen," Journal of Ethics and Social Philosophy.

(2014) “Expressivism and Moore's Paradox," Philosopher's Imprint 14(5). 